\title{
OXIDATIVE STABILITY AND COLD FILTER PLUGGING POINT OF BIODIESEL BLENDS DERIVED FROM FATS AND SOY OIL
}

\author{
João V. Braun ${ }^{\text {a,b }}$, Samuel J. Santos ${ }^{\mathrm{a}, \mathrm{b}}$, Guilherme C. Espíndola ${ }^{\mathrm{a}}$, Gabriel F. de Mattos ${ }^{\mathrm{a}}$, Diego P. Ongaratto ${ }^{\mathrm{a}}$, Diogo M. \\ de Oliveira ${ }^{\mathrm{a}, \mathrm{b}}$, Marlon W. da Silva ${ }^{\mathrm{a}}$, Vinícius Vendrusculo ${ }^{\mathrm{a}}$, Vinícius O. B. dos Santosa, ${ }^{\mathrm{a} b}$, Rodrigo E. Renner ${ }^{\mathrm{b}}$, Fabrício F. \\ Naciuk $^{\mathrm{a}, \mathrm{b}}$, Marcelo V. Marques ${ }^{\mathrm{a}, \mathrm{b}}$ and Luiz A. M. Fontoura ${ }^{\mathrm{a}, \mathrm{b}, *,(1)}$ \\ aUniversidade Luterana do Brasil, 92425-900 Canoas - RS, Brasil

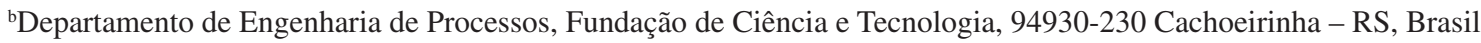

Recebido em 18/05/2020; aceito em 01/07/2020; publicado na web em 21/08/2020

\begin{abstract}
Biodiesel made from oils is rich in polyunsaturated fatty acids methyl esters, and, consequently, presents high tendency to oxidize. Biodiesel made from fats, on the other hand, is mainly comprised by saturated chains. Although it is highly stable, they easily crystalize at low temperatures. Blends from both can exhibit optimized properties. In this work, oxidative stability, expressed by induction period (IP), and cold filter plugging point (CFPP) of blends from palm, palm kernel, babassu, tallow or lard biodiesels with soy one were measured. Biodiesel samples were prepared by two steps transesterification methodology with $\mathrm{KOH}$ catalysis followed by $\mathrm{H}_{2} \mathrm{SO}_{4}$. IP increases, as the fat biodiesel content in the blend is higher, as expected. Blends comprised by $60 \%$ of fat biodiesel by volume had their IP increased from 1.5 (lard) to 2 times (palm kernel), compared to soy one. At this level, IP was found $8 \mathrm{~h}$ or higher, except for palm, which $80 \%$ was required. CFPP was observed at $8{ }^{\circ} \mathrm{C}$ or lower for the blends containing up to $60 \%$ of all the fat biodiesel, except for the palm one, which a $20 \%$ content must not be surpassed. Palm kernel $80 \%$ biodiesel blend reached the Brazilian specification, that is, IP higher than $12 \mathrm{~h}$ and CFPP lower than $5{ }^{\circ} \mathrm{C}$.
\end{abstract}

Keywords: biodiesel; oxidative stability; cold filter plugging point.

\section{INTRODUCTION}

Biodiesel consists of a mixture of fatty acid methyl or ethyl esters, industrially produced by transesterification of oils and fats. ${ }^{1-4}$ The most common triglycerides present in oils and fats are structurally derived from 6 to 24 carbon chain fatty acids. Acyl groups are usually linear and have an even number of carbons. These can be saturated, monounsaturated, or polyunsaturated. In the last case, double bonds are not conjugated. Normally, the double bond configuration is cis. ${ }^{5}$ Biodiesels made from most oils and fats have 16 or 18 carbon chains. From feedstock such as soy or corn oils, chains are predominantly polyunsaturated. From canola oil, chains are mainly monounsaturated. Palm and tallow fats biodiesels are made up of $50 \%$ of saturatedchains fatty esters. Some palm trees fats, such as palm kernel and babassu, produce biodiesel consisting of more than $50 \%$ short chain, 8 to 14 carbons, saturated esters. ${ }^{6-8}$

Biodiesel has been used as total or partial substitute for fossil diesel in compression-ignition engine. As a fuel, it has the advantages of higher cetane number, lubricity and flash point. ${ }^{9-15}$ It is free of sulfur compounds and contributes to the reduction of hydrocarbons and particulate matter emissions. ${ }^{10,12,14,15}$ On the other hand, it has higher hygroscopicity and cold filter plugging point and a lower oxidative stability. ${ }^{915-19}$ In particular, the latter two characteristics are highly dependent on the feedstock.

Biodiesel oxidative stability is normally tested under accelerated conditions in an equipment called Rancimat. At $110^{\circ} \mathrm{C}$, a sample is subjected to an air flow. The volatile secondary oxidative products are transferred from the biodiesel and bubbled into water in a second cell. The aqueous solution has its conductivity measured over time. The stability is expressed as the induction period (IP), which is the interval when the aqueous solution conductivity is greatly enhanced. ${ }^{4,20-22}$

\footnotetext{
*e-mail: lmazzini@uol.com.br
}

Under storage conditions, the oxidation is induced by factors such as air contact, temperature, light, and contaminants such as metals. ${ }^{4,16,19,20}$ Biodiesel degradation results in the formation of deposits and gums that cause the darkening of fuels, filters and injectors plugging, and engine corrosion. ${ }^{16,19,20,23}$

The chain length of diesel hydrocarbons ranges from 10 to 22 carbons. This complex isomeric mixture includes paraffins, isoparaffins, naphthenes and aromatics compounds. ${ }^{24}$ Biodiesel, on the other hand, consists of a much simpler blend of linear chain fatty esters, which tend to crystallize at moderately cold temperatures. ${ }^{15,16,19,25}$ Such crystals can reduce the fuel fluidity and damage the engine. ${ }^{10,16,25,26}$

The tendency to crystalize is greatly influenced by the biodiesel composition. Double bonds with cis configuration, such as those found in oleate $(\mathrm{C} 18: 1)$, linoleate $(\mathrm{C} 18: 2)$, and linolenate $(\mathrm{C} 18: 3)$, put an angular geometry on the chain and hinder crystallization. ${ }^{15,16}$ Conventional oils therefore produce biodiesel with better cold proprieties than fats. Chain length is an important factor as well. The shorter the chain, the lower the melting point, ${ }^{15,27}$ and this can be attributed to the less intense Van der Waals forces. Biodiesels derived from coconut or palm kernel fats, in addition, have better cold properties than the one from palm, for example. ${ }^{28}$

Cold Filter Plugging Point (CFPP) is the most widely used test to describe the tendency of biodiesel to crystalize at low temperature. In the assay, $20 \mathrm{~mL}$ of biodiesel is filtered under standard conditions at a defined temperature. The experiment is repeated at lower temperatures. CFPP is the temperature that requires more than $60 \mathrm{~s}$ to complete the filtration process. The lower the temperature, the longer the filtration time, as the liquid viscosity is higher and the small crystals begin to appear. ${ }^{27,28}$

In order to minimize crystallization tendency, some strategies have been suggested. Winterization, for instance, is the separation of crystals by filtration after biodiesel is subjected to low temperatures. The filtrate has the CFPP diminished; however, part of the fuel is lost. 
Alternatively, flow enhancers can be added to inhibit crystals growth. Additives are often costly. On the other hand, cold flow properties can be enhanced by using branched alcohols in the transesterification reaction. Again, the process is more expansive. Finally, biodiesel from different feedstock can be blended. ${ }^{4,9,16,29-31}$ By optimizing the content of saturated and polyunsaturated chains, the blend composition can minimize the crystallization tendency and maximize the biodiesel stability under oxidative conditions.

In this paper, we evaluated oxidative stability and the cold filter plugging point of biodiesel blends made from a fat such as palm, palm kernel, babassu, tallow, lard, and soy oil in different proportions.

\section{EXPERIMENTAL}

\section{Biodiesel synthesis}

Commercial lard, palm, palm kernel fat and soy oil were used as received. Raw tallow was melted and filtered before use. The biodiesel samples were obtained by transesterification double steps process (TDSP) as described by Guazatto et al. ${ }^{32}$ About $200 \mathrm{~mL}$ of the feedstock were introduced into a $1.0 \mathrm{~L}$ glass reactor preheated at $65^{\circ} \mathrm{C}$. Then, a solution of $1.1 \mathrm{~g}$ of $\mathrm{KOH}$ in $80 \mathrm{~mL}$ of $\mathrm{MeOH}$ was transferred to the reactor. The mixture was vigorously stirred at $65^{\circ} \mathrm{C}$ for $30 \mathrm{~min}$. After this time, a solution of $1.0 \mathrm{~mL}$ of $\mathrm{H}_{2} \mathrm{SO}_{4}$ in $40 \mathrm{~mL}$ of $\mathrm{MeOH}$ was added over the mixture. The mixture was further stirred at the same temperature for $60 \mathrm{~min}$. After that, the stirring was stopped, and the mixture was allowed to separate. The upper layer was isolated, filtered, and washed three times with $100 \mathrm{~mL}$ of hot water $\left(70{ }^{\circ} \mathrm{C}\right)$. Finally, biodiesel was subjected to evaporation in a vacuum in order to eliminate volatile impurities.

Esters content and composition: the content of palm kernel and babassu biodiesel esters were determined by Hydrogen Nuclear Magnetic Resonance as described by Guzatto et al. ${ }^{32}$ The spectra were acquired using a Varian Mercury $400 \mathrm{MHz}$ Spectrometer. Samples $(50 \mathrm{mg})$ were prepared in $\mathrm{CDCl}_{3}(0.5 \mathrm{~mL})$. Lard, tallow, soy and palm biodiesel esters contents were determined by GC-FID as described by Braun et al. ${ }^{6,33}$ Analyses were performed in a Shimadzu 2010 gas chromatography equipped with a flame ionization detector, AOC 20i auto-sampler and OV CARBOWAX $20 \mathrm{M}(30 \mathrm{~m}$ x $320 \mu \mathrm{m}$ x $0.25 \mu \mathrm{m})$. Hexadecyl acetate or hexadecyl propionate was used as internal standard. Biodiesel compositions were determined by relative peak areas of individual fatty esters. For babassu and palm kernel biodiesels, response factors were used as described by Visentainer. ${ }^{34}$ Free and total glycerin were determined in palm kernel and babassu biodiesels as described in the standard method, EN 14105. ${ }^{35}$ Induction period: oxidative stability expressed as induction period was determined in a Rancimat model 873 Metrohm using the standard method EN 14112. ${ }^{36}$ Cold filter plugging point were determined with FPP 5GSA ILA by PAC using the standard method ASTM 6371. ${ }^{37}$ Blends of fat biodiesels with soy oil biodiesel were prepared by mixing the appropriate volumes of each.

\section{RESULTS AND DISCUSSION}

Methyl biodiesel of lard, tallow, palm, palm kernel and babassu fats and soy oil were easily prepared using the TDSP methodology. Palm, tallow, lard and soy biodiesels had their ester contents estimated as $98 \%$ or higher by gas chromatography. The ester contents of palm kernel and babassu biodiesels cannot be determined by GC-FID, unless the peak areas are corrected by response factors. However, this is not the EN 14103 standard $^{38}$ orientation, and the ester content of 94.6 and $92.5 \%$ was found for palm kernel and babassu biodiesels, respectively. Ester content can also be estimated by ${ }^{1} \mathrm{H}$ NMR. In this case, values of $99.4 \%$ and $97.7 \%$ were obtained for palm kernel and babassu, respectively. TDSP is a well-established method and the quality of biodiesel obtained by this way is well known. Just for control, these two biodiesels had their monoglyceride (MG), diglyceride (DG), triglyceride (TG), and glycerol contents determined by GC. DG and TG were not detected. MG was estimated as $0.11 \%$ for palm kernel and $0.06 \%$ for babassu. Glycerol content was estimated as $0.01 \%$ for the latter but was not detected for the former.

Table 1 shows individual fatty esters content for each biodiesel.

Table 1. Palm kernel, babassu, palm, tallow, lard fats, and soy oil biodiesels compositions

\begin{tabular}{lcccccc}
\hline$\%)$ & $\begin{array}{c}\text { palm } \\
\text { kernel }\end{array}$ & babassu & palm & tallow & lard & soy \\
\hline C8:0 & 2.8 & 4.8 & ND & ND & ND & ND \\
C10:0 & 3.0 & 4.8 & ND & ND & ND & ND \\
C12:0 & 48.8 & 45.7 & ND & ND & ND & ND \\
C14:0 & 15.5 & 16.9 & 0.9 & 1.8 & 1.3 & 0.1 \\
C16:0 & 8.2 & 9.0 & 41.9 & 29.0 & 22.0 & 10.9 \\
C16:1 & ND & ND & ND & 4.7 & 2.4 & ND \\
C17:0 & ND & ND & ND & 1.6 & 0.5 & ND \\
C18:0 & ND & ND & 3.2 & 14.9 & 10.0 & 2.1 \\
C18:1 & 18.1 & 15.4 & 41.8 & 45.9 & 43.7 & 25.8 \\
C18:2 & 2.4 & 2.0 & 12.1 & 1.3 & 19.4 & 56.4 \\
C18:3 & $\mathrm{ND}$ & $\mathrm{ND}$ & 0.2 & 0.8 & 0.7 & 4.8 \\
\hline$\Sigma_{\text {SCFE }}$ & 70.1 & 72.2 & 0.9 & 1.8 & 1.2 & 0.1 \\
$\Sigma_{\text {SFE }}$ & 78.3 & 81.2 & 46.0 & 47.3 & 33.7 & 13.1 \\
$\Sigma_{\text {PUFE }}$ & 2.4 & 2.0 & 12.3 & 2.1 & 20.1 & 61.1 \\
\hline
\end{tabular}

Short chain fatty esters (SCFE), saturated fatty esters (SFE), and polyunsaturated fatty esters (PUFE). CX:Y $-\mathrm{X}$ is the acyl group length and $\mathrm{y}$ is the double bond number. ND - not detected.

The composition of the palm kernel and babassu biodiesel is markedly different from the others. Oleate is the main fatty ester present in lard and tallow biodiesel (ca. 45\%). Palm biodiesel is also rich in C18:1. Tallow biodiesel has low linoleate content compared to the other two. Soy biodiesel, on the other hand, is predominantly polyunsaturated.

Table 2 shows the blends induction periods (IP). Experiments were conducted for $15 \mathrm{~h}$. Pure soy biodiesel ( $0 \%$ fat) showed an IP of approximately $5 \mathrm{~h}$. Depending on the sample, minor variations were found. Small additions of fat biodiesel caused slight increments. Pure fat biodiesels $(100 \%)$ showed an induction period of $9 \mathrm{~h}$ or more. Blends comprised by $60 \%$ of fat biodiesel by volume had their IP

Table 2. Fats and soy biodiesels blends induction periods (IP)

\begin{tabular}{lccccc}
\hline \multirow{2}{*}{ Fat\% } & \multicolumn{5}{c}{ IP / h } \\
\cline { 2 - 6 } & palm kernel & Babassu & palm & tallow & lard \\
\hline 0 & 4.5 & 4.5 & 4.5 & 5.4 & 5.4 \\
20 & 4.5 & 4.4 & 4.9 & 6.8 & 6.3 \\
40 & 6.2 & 6.4 & 5.6 & 8.1 & 7.1 \\
60 & 9.1 & 7.9 & 7.3 & 10.9 & 7.9 \\
80 & 13.8 & 8.8 & 10.5 & 15.0 & 8.1 \\
100 & $>15$ & 10.9 & $>15$ & $>15$ & 9.4 \\
\hline
\end{tabular}


increased from 1.5 (lard) to 2 times (palm kernel), compared to soy one.

Figure 1 shows the induction period (IP) of biodiesel blends as a function of the fat biodiesel content on the blend. Of course, in all the cases, IP is enhanced with addition of fat biodiesel over the soy biodiesel, since the content of the polyunsaturated chains responsible for the oxidation process, is reduced.

Among the fats, lard is the richest in linoleate and is the most susceptible to oxidation. Palm kernel and babassu present polyunsaturated content as low as tallow. However, addition of these vegetable fats biodiesels over soy seems not to be as effective as the latter. It is noteworthy that induction period is a parameter that indirectly evaluate the biodiesel oxidative stability. In the assay conditions, shorter chains, like those in palm kernel and babassu biodiesels, can be arrested by the Rancimat air current from the sample cell to the aqueous solution sample and enhance its conductivity, consequently diminishing the induction period.

ASTM D6751-18, the Standard Specification for Biodiesel $(\mathrm{B} 100)^{39}$ specifies $3 \mathrm{~h}$ as the lower induction period limit. Soy biodiesel, or any of its blends, thus meets the specification. Brazilian legislation, ${ }^{40}$ by its turn, defines $12 \mathrm{~h}$ as the inferior limit (dashed line in Figure 2). This is observed only in $80 \%$ of palm kernell or tallow blends.

Unlike the hydrocarbons that make up diesel, the fatty esters that constitute biodiesel can be unsaturated and the composition is strictly dependent on the feedstock. In the presence of oxygen, the oxidative degradation of the ester chain is carried out by a radical mechanism, Scheme 1 .

A C-H homolytic fission removes an allylic or bis-allylic hydrogen (1), producing a free radical (2) which is stabilized by resonance. The stabilization is especially high in bis-allylic free radical. In this case, the radical formation activation energy is reduced and thus the reaction rate is increased. ${ }^{19,20}$ For this reason the relative oxidation rates of oleate (C18:1), linoleate (C18:2), and linolenate (C18:3) are 1:41:98. ${ }^{13,15,16,19-21}$ The higher the polyunsaturated fatty esters content, the lower the biodiesel stability. Biodiesel obtained from fats like tallow or palm is more stable under oxidative conditions than those produced from oils, such as soy or corn. ${ }^{19}$ Primary

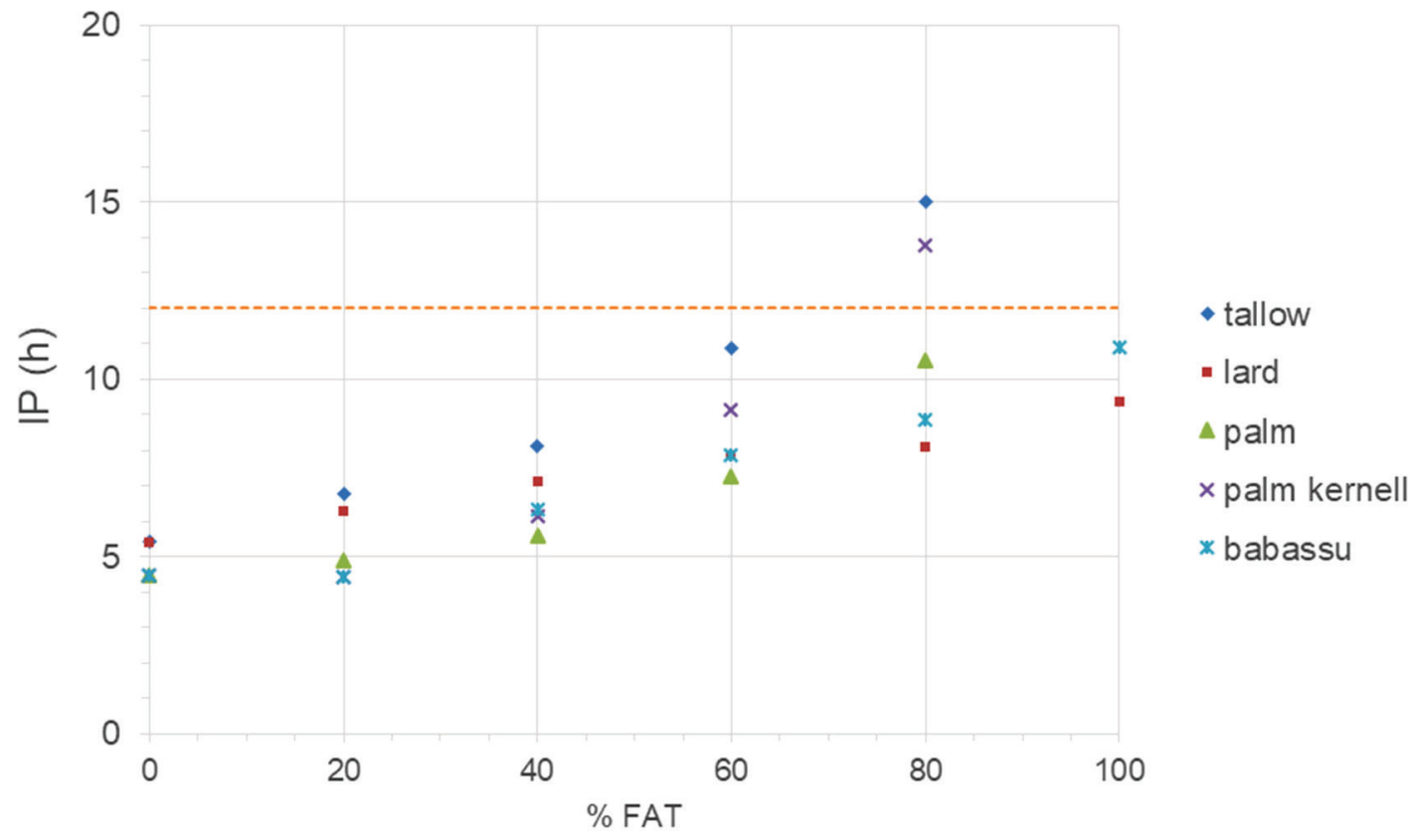

Figure 1. Induction period of biodiesel blends as function of fat biodiesel content

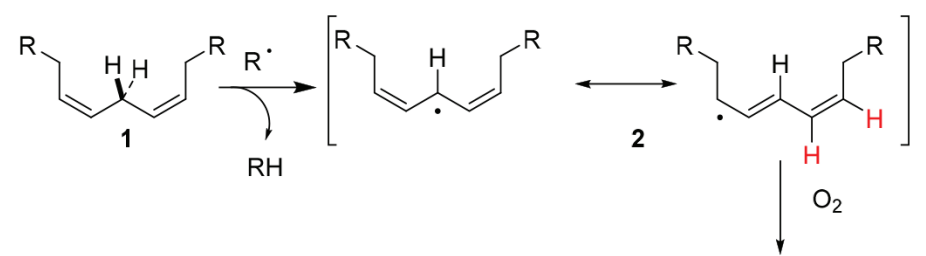

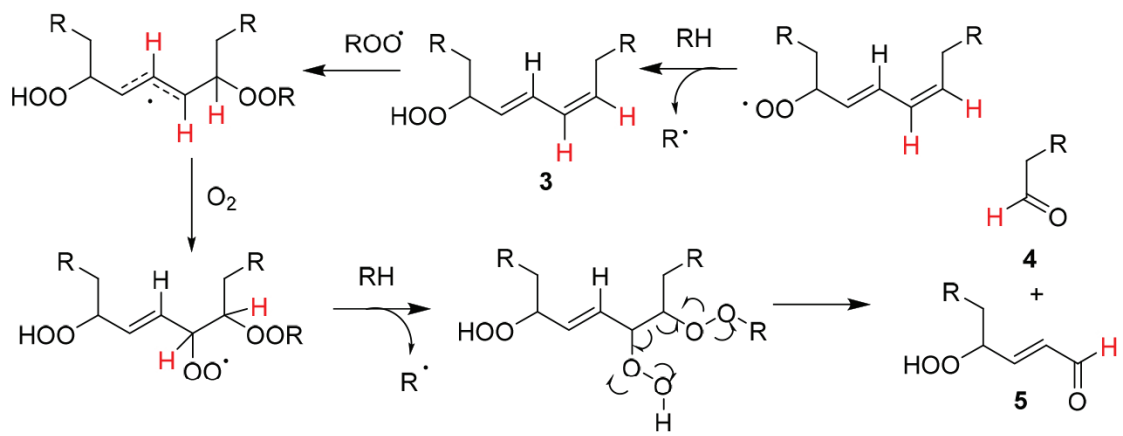




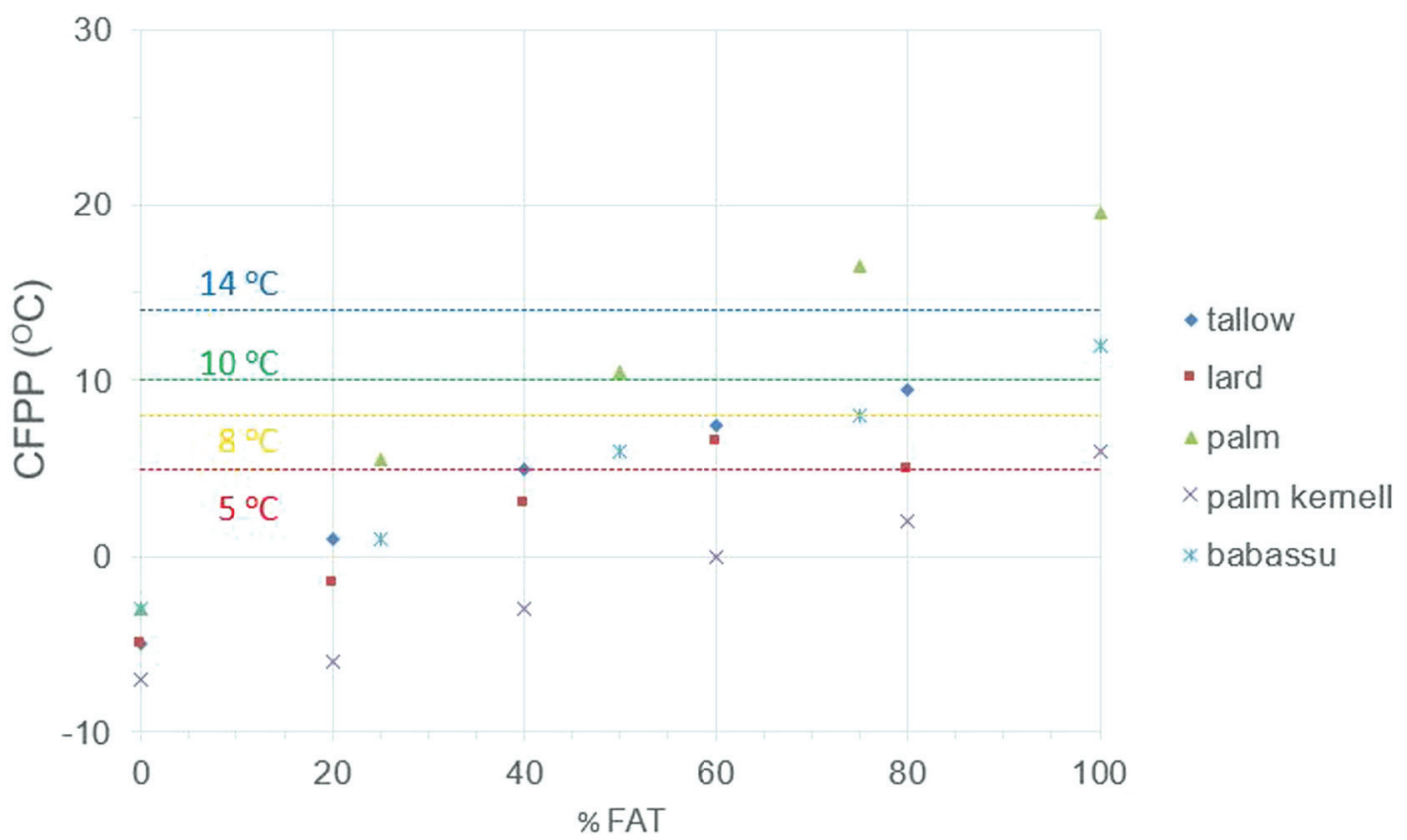

Figure 2. Cold Filter Plugging Point (CFPP) of biodiesel blends as function of fat biodiesel content

oxidation products are hydroperoxydes (3); however, as the oxidation progresses, short chains carbonyl compounds like ketones, aldehydes and carboxylic acids $(\mathbf{4}, \mathbf{5})$ are formed. ${ }^{16,18-22}$

Table 3 shows the cold filter plugging points (CFPP) of soy biodiesel and its blends with palm kernel, babassu, palm, tallow and lard. Pure soy biodiesel ( $0 \%$ fat) showed CFPP from -7 to $-3{ }^{\circ} \mathrm{C}$, depending on the sample. Small additions of fat biodiesel caused slight CFPP increments.

Table 3. Fats and soy biodiesels blends cold filter plugging point (CFPP)

\begin{tabular}{lccccc}
\hline \multirow{2}{*}{ Fat\% } & \multicolumn{5}{c}{$\mathrm{CFPP}\left({ }^{\circ} \mathrm{C}\right)$} \\
\cline { 2 - 6 } & palm kernel & babassu & palm & tallow & lard \\
\hline 0 & -7.0 & -3.0 & -5.0 & -5.0 & -5.0 \\
20 & -6.0 & & -1.5 & 1.0 & -1.5 \\
25 & & 1.0 & & & \\
40 & -3.0 & & 3.0 & 5.0 & 3.0 \\
50 & & 6.0 & & & \\
60 & 0.0 & & 6.5 & 7.5 & 6.5 \\
75 & & 8.0 & & & \\
80 & 2.0 & & 5.0 & 9.5 & 5.0 \\
100 & 6.0 & 12.0 & 19.5 & & \\
\hline
\end{tabular}

Figure 2 shows the cold filter plugging point (CFPP) of biodiesel blends as a function of the fat biodiesel content.

It is expected that palm and tallow should have greater impact on cold flow properties than lard, since they have higher contents of saturated chains. Babassu and palm kernel, on the other hand, even though they are highly saturated, mostly contain short chains, and lower temperature filter plug. ASTM D675137 establishes the cloud point as a parameter to evaluate the cold flow properties of biodiesel instead of the cold filter plugging point. In Brazil, CFPP higher limit depends on the period of the year and the region. It cannot be higher than $14{ }^{\circ} \mathrm{C}$ (blue dashed line) in the summer time. Besides palm, all soy/fat biodiesel blends exhibit CFPP below the limit. In the winter, the limits are 10,8 , or $5^{\circ} \mathrm{C}$ (green, orange and red lines, respectively) depending on the reagion. Palm kernell biodiesel can be added to soy in any proportion. Tallow, lard, and babassu can be added from 40 to $80 \%$ depending on the region.

\section{CONCLUSIONS}

Blends of fats and soy oil biodiesels were prepared and evaluated for their oxidative stability and cold filter plugging point. The addition of fats biodiesel over soy oil biodiesel improved its stability; however, its crystallization tendency was enhanced. Of the fats, tallow biodiesel addition showed the highest effect over the induction period (IP). In this case, IP was measured as $12 \mathrm{~h}$ or more only in $80 \%$ of palm kernell or tallow blends. The higher cold filter plugging point (CFPP) observed in the fats biodiesel is a disadvantage. CFPP was observed to be 5 and $8{ }^{\circ} \mathrm{C}$ for the blends containing up to 40 and $60 \%$ of the fat biodiesel, respectively, except for the palm biodiesel, which required not exceeding the $20 \%$ content. Palm kernel biodiesel, on the other side, required up to $90 \%$. In summary, it can be concluded that palm kernel biodiesel blend with content of $80 \%$ reached the specifications for the two properties, IP and CFPP.

\section{ACKNOWLEDGEMENTS}

Fundação de Amparo à Pesquisa do Rio Grande do Sul - FAPERGS

\section{REFERENCES}

1. Schuchardt, U.; Sercheli, R.; Vargas, R. M.; J. Braz. Chem. Soc. 1998, 9, 199.

2. Pinto, A. C.; Guarieiro, L. L. N.; Rezende, M. J. C.; Ribeiro, N. M.; Torres, E. A.; Lopes, W. A.; Pereira, P. A. P.; de Andrade, J. B.; J. Braz. Chem. Soc. 2005, 16, 1313.

3. Othman, M. F.; Adam, A.; Naja, G.; Mamat, R.; Renewable Sustainable Energy Rev. 2017, 80, 694.

4. Knothe, G.; Razon, L. F.; Prog. Energy Combust. Sci. 2017, 58, 36.

5. Pitts, S. J.; Thomson, C. I.; J. Forensic Sci. 2011, 48, 16.

6. Braun, J. V.; dos Santos, V. O. B.; Fontoura, L. A. M.; Pereira, E.; Napp, A.; Seferin, M.; Lima, J.; Ligabue, R.; Vainstein, M. H.; Quim. Nova 2017, 40, 1111. 
7. Llamas, A.; García-martínez, M. J.; Al-lal, A.; Canoira, L.; Fuel 2012, 102, 483.

8. Llamas, A.; Al-lal, A.; Hernandez, M.; Canoira, L.; Energy Fuels 2012, 26, 5968

9. Sierra-cantor, J. F.; Guerrero-fajardo, C. A.; Renewable Sustainable Energy Rev. 2017, 72, 774.

10. Issariyakul, T.; Dalai, A. K.; Renewable Sustainable Energy Rev. 2014, $31,446$.

11. Ashraful, A. M.; Masjuki, H. H.; Kalam, M. A.; Fattah, I. M. R.; Imtenan, S.; Shahir, S. A.; Mobarak, H. M.; Energy Convers. Manage. 2014, 80, 202.

12. Ramírez-Verduzco, L. F.; Rodríguez-Rodríguez, J. E.; Jaramillo-Jacob, A. R.; Fuel 2012, 91, 102.

13. Knothe, G.; Fuel Process. Technol. 2005, 86, 1059.

14. Demirbas, A.; Energy Convers. Manage. 2008, 49, 2106.

15. Knothe, G.; Energy Fuels 2008, 1358.

16. Lanjekar, R. D.; Deshmukh, D.; Renewable Sustainable Energy Rev. 2016, 54, 1401.

17. Sajjadi, B.; Aziz, A.; Raman, A.; Arandiyan, H.; Renewable Sustainable Energy Rev. 2016, 63, 62.

18. Pullen, J.; Saeed, K.; Renewable Sustainable Energy Rev. 2012, 16, 5924.

19. Saluja, R. K.; Kumar, V.; Sham, R.; Renewable Sustainable Energy Rev. 2016, 62, 166

20. Yaakob, Z.; Narayanan, B. N.; Padikkaparambil, S.; Unni K, S.; Akbar P.; M.; Renewable Sustainable Energy Rev. 2014, 35, 136.

21. Knothe, G.; Fuel Process. Technol. 2007, 88, 669.

22. Focke, W. W.; Westhuizen, I. V. D.; Oosthuysen, X.; Thermochim. Acta 2016, 633, 116.

23. Kumar, N.; Fuel 2017, 190, 328.

24. Bai, L.; Smuts, J.; Schenk, J.; Cochran, J.; Schug, K. A.; Fuel 2018, 214, 521.
25. Islam, M. M.; Hassan, M. H.; Kalam, A.; Wahidah, N.; Hossain, M. M.; J. Cleaner Prod. 2016, 137, 322.

26. Verma, P.; Sharma, M. P.; Dwivedi, G.; Energy Rep. 2016, 2, 8 .

27. Knothe, G.; Dunn, R. O.; J. Am. Oil Chem. Soc. 2009, 843.

28. Rupilius, W.; Ahmad, S.; Eur. J. Lipid Sci. Technol. 2007, 109, 433.

29. Nainwal, S.; Sharma, N.; Sharma, A. S.; Jain, S.; Jain, S.; Energy 2015, 89,702 .

30. Liu, J.; Shen, Y.; Nan, Y.; Tavlarides, L. L.; Fuel 2016, 178, 23.

31. Anwar, A.; Garforth, A.; Fuel 2016, 173, 189

32. Guzatto, R.; de Martini, T. L.; Samios, D.; Fuel Process. Technol. 2011, 92, 2083.

33. Pereira, E.; Napp, A.; Braun, J. V.; Fontoura, L. A. M.; Seferin, M.; Ayres, J.; Ligabue, R.; Passaglia, L. M. P.; Vainstein, M. H.; J. Chromatogr. B 2018, 1093-1094, 134

34. Visentainer, J. V.; Quim. Nova 2012, 35, 274.

35. European Committee for Standardization. EN 141105:2001 - Fat and oil derivatives - Fatty Acid Methyl Esters (FAME) - Determination of free and total glycerol and mono-, di-, triglyceride contents. CEN: Brussels, 2016.

36. European Committee for Standardization. EN 14112:2016 - Fat and oil derivatives - Fatty Acid Methyl Esters (FAME) - Determination of oxidation stability (accelerated oxidation test). CEN: Brussels, 2016.

37. American Society for Testing and Materials (ASTM). D $6371-05$. Standard Test Method for Cold Filter Plugging Point of Diesel and Heating Fuels. ASTM: West Conshohocken, 2005.

38. European Committee for Standardization. EN 14103:2011 - Fat and oil derivatives - Fatty Acid Methyl Esters (FAME) - Determination of ester and linolenic acid methyl ester contents. CEN: Brussels, 2016.

39. American Society for Testing and Materials (ASTM). ASTM D6751 - 11b. Standard specification for biodiesel fuel blend stock (B100) for middle distillate fuels. ASTM: West Conshohocken, 2011.

40. Agência Nacional do Petróleo, Gás Natural e Biocombustíveis. Resolução ANP No 45 de 25 de agosto de 2014. ANP: Brasília, 2014 